\title{
Glycemic Variability and CNS Inflammation: Reviewing the Connection
}

\author{
Charles Watt, Elizabeth Sanchez-Rangel and Janice Jin Hwang * \\ Section of Endocrinology, Yale School of Medicine, New Haven, CT 06510, USA; charles.watt@yale.edu (C.W.); \\ elizabeth.sanchezrangel@yale.edu (E.S.-R.) \\ * Correspondence: janice.hwang@yale.edu
}

Received: 19 November 2020; Accepted: 14 December 2020; Published: 21 December 2020

\begin{abstract}
Glucose is the primary energy source for the brain, and exposure to both high and low levels of glucose has been associated with numerous adverse central nervous system (CNS) outcomes. While a large body of work has highlighted the impact of hyperglycemia on peripheral and central measures of oxidative stress, cognitive deficits, and vascular complications in Type 1 and Type 2 diabetes, there is growing evidence that glycemic variability significantly drives increased oxidative stress, leading to neuroinflammation and cognitive dysfunction. In this review, the latest data on the impact of glycemic variability on brain function and neuroinflammation will be presented. Because high levels of oxidative stress have been linked to dysfunction of the blood-brain barrier (BBB), special emphasis will be placed on studies investigating the impact of glycemic variability on endothelial and vascular inflammation. The latest clinical and preclinical/in vitro data will be reviewed, and clinical/therapeutic implications will be discussed.
\end{abstract}

Keywords: glycemic variability; oxidative stress; neuroinflammation; cognitive dysfunction; vascular dysfunction; endothelial inflammation; blood-brain barrier; diabetes

\section{Introduction}

Glucose, the predominant energy source for the body and particularly for the brain [1], is transported across the blood-brain barrier and ultimately metabolized in the mitochondria to generate ATP [2]. In the process of oxidative phosphorylation, reactive oxygen species (ROS) are generated; thus, in disease states such as Type 1 and Type 2 diabetes, exposure to abnormal glucose levels can lead to high levels of oxidative stress and inflammation $[3,4]$. While much attention has been focused on the impact that chronic hyperglycemia [5] and hypoglycemia [6] have on the generation of oxidative stress and inflammation, a growing body of evidence has shown that fluctuations in blood glucose levels, or glycemic variability (GV), may also drive excessive ROS and oxidative stress and lead to vascular and cardiovascular complications [7-9]. This review will summarize the recent literature on the impact of fluctuations in glucose, neuroinflammation, and neurological function.

The definitions of glycemic variability have changed over time, particularly with the recent widespread use of technologies such as continuous glucose monitors (CGM), which were first approved in 1999 for clinical use in patients with Type 1 diabetes (T1DM) [10] and which measure interstitial blood glucose levels. Prior to CGM use, the term glycemic variability was often used to describe the variability between glycated hemoglobin $(\mathrm{HbA} 1 \mathrm{C})$ measurements or the direct blood glucose measurements made at clinical visits. These measurements were often taken weeks or months apart. With advances in CGM technology, the term "glycemic variability" has been adopted to indicate changes in peripheral glucose on the order of minutes rather than weeks. For coherence in this review, GV measured by inter-visit laboratory tests will be labeled "long-term" GV and GV measured through 
CGMs will be termed "short-term" GV. A short guide to common acronyms in GV is included in Table 1. For a more thorough review of GV metrics, see Rodbard 2009 [11] and Umpierrez 2018 [12].

Table 1. Common terms used in the study of glycemic variability.

\begin{tabular}{|c|c|c|}
\hline Abbreviation & Full Name & Description \\
\hline Short-Term GV & $\begin{array}{l}\text { Measures GV fluctuations in } \\
\text { minute to hour increments }\end{array}$ & $\begin{array}{l}\text { Typically measured using a CGM and reported with } \\
\text { a variety of statistical measures }\end{array}$ \\
\hline Long-Term GV & $\begin{array}{l}\text { Measures GV on the scale of } \\
\text { weeks to months }\end{array}$ & $\begin{array}{l}\text { Typically reported as standard deviation of inter-visit } \\
\qquad \mathrm{HbA1C}\end{array}$ \\
\hline $\mathrm{HbA} 1 \mathrm{C}$ & GlycatedHemoglobin Assay & Reported as percentage of glycated hemoglobin \\
\hline CGM & Continuous Glucose Monitor & $\begin{array}{l}\text { A wearable medical device that regularly records } \\
\text { blood sugar }\end{array}$ \\
\hline
\end{tabular}

It is important to highlight that in many studies, it may be difficult to distinguish between the effects of glycemic control and glycemic variability. Glycemic control is most commonly measured by the $\mathrm{HbA1C}$ (glycated hemoglobin fraction), which is the gold standard measurement for measuring the risk of developing diabetes-related complications [13,14]. The HbA1C is largely the result of a slow glycation of hemoglobin, which is dependent on circulating glucose levels and thus, is used as an average blood glucose concentration over the past $\sim 3$ months (the approximate life span of a typical red blood cell) [15]. Thus, the HbA1C does not provide any information about fluctuations in glucose levels during that period. Some clinical trials have reported that improved glycemic control can be associated with reduced glycemic variability [16]. Other studies have shown that the intensification of diabetes therapy leads to higher rates of hypoglycemia and variability [17]. Thus, it may be challenging to resolve the impact of glycemic control and variability independently. With the more frequent use of CGM technology as well as other biological markers such as 1,5 anhydro-d-glucitol [18] and glycated albumin [19], which may be more reflective of some measures of glycemic variation, such as postprandial glucose excursions, future studies may provide more insight into the independent effects of glucose control and variability.

\section{Glycemic Variability, Oxidative Stress, and Inflammation}

Reactive oxygen species are generated under normoglycemic conditions during cellular glucose metabolism $[2,3]$. While once considered simply by-products of cellular metabolism, ROS are now understood to play important roles in intracellular signaling, particularly in immune cells [20]. However, the balance between ROS production and antioxidant defense mechanisms is altered in states of hyper- and hypoglycemia. This imbalance then leads to increased oxidative stress as well as abnormal immune function and inflammation [4,21].

Hyperglycemia can drive excess ROS via multiple different pathways including: increased flux through the polyol pathway [22,23] and hexosamine pathway [24,25]; increased formation of advanced glycation end products [26,27]; and increased activation of protein kinase C through diacylglycerol [28,29]. A more detailed exploration of these mechanisms can be found in Brownlee 2001 [30] and it is very well-established that these underlying mechanisms contribute to the hyperglycemia-associated microvascular complications of diabetes including retinopathy, nephropathy, and neuropathy [30]. Although the mechanisms remain less well defined than in hyperglycemia, hypoglycemia also increases oxidative stress, likely via dysfunctional mitochondrial bioenergetics [31-33]. Mild hypoglycemia (2.5 mM) induces apoptosis and oxidative stress in cultured Schwann cells, and, in animal models, exposure to repeated episodes of hypoglycemia changes the expression levels of redox genes as well as increases levels of lipid peroxidation and protein carbonylation [34]. In patients with Type 2 diabetes mellitus (T2DM) studied using a hyperinsulinemic hypoglycemic clamp, mild hypoglycemia $(2.7 \mathrm{mM})$ induces the production of markers of oxidative stress and inflammation including c-reactive protein and urinary free 8-isoprostoglandin F2 $\alpha$ (8-iso PGF2 $\alpha$ ) [35]. 
Given the body of evidence that both hyperglycemia and hypoglycemia can independently lead to increased oxidative stress and inflammation, it is not surprising that fluctuations in glucose level may lead to even greater exposure to oxidative stress and inflammation [36,37]. The Diabetes Complication and Control Trial (DCCT) was the landmark trial that established a clear link between glycemic control (measured by $\mathrm{HbA1C}$ ) and the risk of developing microvascular complications of diabetes [38]. However, while the DCCT found that mean HbA1C values were the dominant factor in predicting future microvascular complications, glycemic control did not solely account for the risk of complications [38], raising the possibility that additional factors such as glycemic variability could be contributing to patient outcomes $[39,40]$. To begin measuring the respective impact of hyperglycemia compared to glycemic variability, Monnier and colleagues [36] examined the relationship between CGM-measured metrics of glycemic variability and markers of oxidative stress. While individuals with T2DM had higher levels of 8-iso PGF2 $\alpha$ compared to non-diabetic control subjects, there was no relationship between 8 -iso PGF2 $\alpha$ and any metrics of glycemic control including $\mathrm{HbA} 1 \mathrm{C}$ or fasting glucose levels. However, higher glycemic variability was strongly correlated with higher levels of 8 -iso PGF2 $\alpha$ [36]. Two subsequent studies amongst individuals with T1DM [41] and T2DM [42] were not able to replicate these findings; however, there were differences in methodology as well as severity of diabetes in the subjects. More recently, plasma levels of 1,5-anhydroglucitol (1,5-AG) and glycated albumin, which may be more reflective of postprandial glucose excursions, [18] were found to be more closely associated with markers of oxidative stress than HbA1C [43]. Moreover, Ohara and colleagues reported improvements in markers of oxidative stress amongst 67 patients with T2DM following a 6-month intervention to reduce postprandial glucose excursions and glycemic variability [44]. While these studies point to a growing recognition that glycemic variability may be associated with oxidative stress and inflammation, they also highlight how differences in the methodology used to measure GV may have a significant impact on the interpretation of results. In fact, two separate reviews by Nalysnyk et al. [45] and Siegelaar et al. [46], which mainly focused on the impact of GV on peripheral complications of diabetes, drew fundamentally different conclusions about whether GV should be considered a risk factor for diabetes-related complications. With the recent publication of a consensus statement on the use of CGM to measure GV [47], future studies will include more standardized metrics for measuring GV, which will greatly improve the reproducibility of findings as well as improve our ability to interpret results.

Relatively fewer studies have focused specifically on the impact of GV on the central nervous system (CNS), despite strong evidence that both hyperglycemia and hypoglycemia have a profound impact on CNS function $[48,49]$. Thus, the remainder of this review will focus specifically on the impact of GV on the CNS (Figure 1).

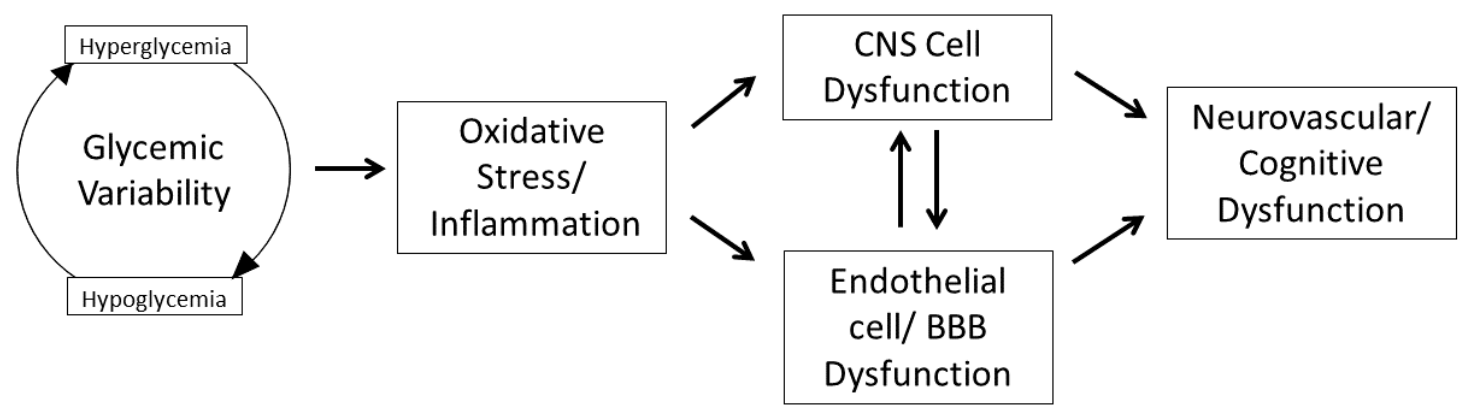

Figure 1. The impact of glycemic variability in the central nervous system.

\section{Impact of GV on Central Nervous System Inflammation}

The interactions between various brain cell types and the brain microvessel endothelial cells, often termed the neurovascular unit (NVU), are critical to maintaining CNS function. A growing body of the literature has described the impact of diabetes on components of the NVU, including: astrocytes, 
which are less populous and disconnected from endothelial cells [50]; pericytes, which are similarly diminished and retracted [51]; oligodendrocytes, which are decreased in number and short-lived [52]; microglia, which are abnormally polarized [53]; and endothelial cells, which are rendered less dense and more permeable [54-56]. However, very little is known about the impact of glycemic variability on the integrity of the NVU.

\subsection{GV on Endothelium and Blood-Brain Barrier}

Few studies have looked specifically at the impact of GV on brain endothelial function. In studies using brain endothelial cell lines, a brief acute exposure to hyperglycemia was associated with greater endothelial barrier dysfunction as measured by disruptions in transendothelial electrical resistance [57]. Similarly, in rodent models of diabetes, ex vivo analysis of brain microvessels revealed upregulation of inflammatory markers and evidence that glycemic variation leads to endothelial disruption [58]. These studies are consistent with other studies using human aortic endothelial [59] and umbilical [60,61] cell lines. In rodent models, glucose fluctuations have been associated with blood-brain barrier (BBB) dysfunction [62] as well as altered brain glucose transport [63]. Glut1 expression in brain endothelial cells has been shown in vitro to be increased following exposure to hypoglycemia [64] and the distribution of Glut1 on luminal compared to abluminal surfaces of microvessel endothelial cells may also be altered with hypoglycemia [63]. Conversely, chronic hyperglycemia may also be associated with decreased expression of Glut1 at the BBB [65]. One of the few studies that studied GV directly found that repeated glucose fluctuations had a larger effect on BBB transporters than acute, sustained glucose changes [58]. In humans, poorly controlled T1DM and T2DM have both been associated with diminished brain glucose [66,67].

In the human brain, virtually no studies have examined the impact of glycemic variability directly on the blood-brain barrier. Amongst T1DM patients, higher glycemic variability is associated with altered brain glucose transport capacity [68], which could have implications for hyperglycemia-driven ROS production and oxidative stress. A series of studies by Ceriello and colleagues used experimentally induced glucose fluctuations to investigate the impact of GV on endothelial function and inflammation. In one study, acute hyperglycemia resulted in peripheral endothelial dysfunction measured by flow-mediated dilation, increased inflammation measured by 8 -iso prostaglandin F2 $\alpha$, and higher levels of oxidative stress measured by plasma nitrotyrosine [69]. Additional studies using similar experimental methods found that the degree of endothelial dysfunction and the levels of oxidative stress were higher with repeated glucose oscillations compared to a single step in glycemia [70]. Moreover, inducing extremes in glucose levels such as a period of hypoglycemia followed by hyperglycemia was associated with worse endothelial function as well as greater oxidative stress and inflammation [71]. More recently, amongst individuals with poorly controlled T2DM, higher CGM measured short-term GV, measured by mean absolute glycemic excursion (MAGE), was associated with an altered endothelial cell epigenetic profile on P66shc, an adapter protein that is a key driver of mitochondrial oxidative stress [72]. A similar study in patients with T1DM demonstrated a positive correlation between MAGE and higher levels of endothelial progenitor cells, which are typically produced to repair vascular damage [73].

\subsection{GV and Microglia, Neuronal, and Astroglial Cells}

Microglia, the resident macrophages of the central nervous system, comprise nearly $15 \%$ of cells in the brain [74] and play a critical role in synaptic pruning [75-77] and the phagocytosis of cellular debris [78]. Resting microglia are tightly regulated by interactions with neurons with microglia serving protective functions [79]. For example, when provided with signals that indicate the presence of tissue damage or pathogens, microglia become activated and carry out repair functions. However, excessive activation may lead to the release of inflammatory cytokines, chemokines, reactive oxygen species, and nitric oxide, which can lead to neuronal dysfunction and death [80-83]. Exposure to chronic hyperglycemia has been associated with activation of microglia [84]. Furthermore, when studying 
the mouse microglial BV-2 cell line, exposure to glucose fluctuations resulted in increased markers of metabolic stress leading to apoptosis and/or autophagy [85] as well as leading to shifts in microglial polarization to the inflammatory M1 phenotype [53].

Several studies have also shown the direct impact of GV on neuronal and astroglial cells [86,87]. An in vitro study of neuroblastoma cells found that 6-h fluctuations of glucose from 90 to $900 \mathrm{mg} / \mathrm{dl}$ resulted in decreased metabolic activity measured by a reduction in tetrazolium salts, and increased apoptotic gene expression [86]. A similar in vitro experiment on C6 astroglial cells exposed to hyperglycemia $(12 \mathrm{mM})$ or glucodeprivation $(0 \mathrm{mM})$ exhibited decreased cellular proliferation and glucose uptake as well as increased mitochondrial dysfunction, DNA damage, and ROS production [87]. An in vivo study comparing glucose fluctuation to constant hyperglycemia in female Goto-Kakizaki (GK) rats used twice daily intraperitoneal insulin injections to model GV and found that GV caused significantly more neuron apoptosis than hyperglycemia alone [88]. In addition, GV-GK rats had higher levels of inflammatory markers including tumor necrosis factor-alpha (TNF $\alpha$ ) and interleukin-1beta [88]. A comparable study of male Sprague Dawley rats with streptozotocin-induced diabetes found similar results [89]. GV caused by the tri-daily alternation of intraperitoneal injections of glucose and insulin induced an inflammatory response measured by TNF $\alpha$ and interleukin-6 (Il-6) [89]. Furthermore, GV led to observable neuronal structural damage in myelin sheaths and axons when viewed via electron microscopy, which may explain the rats' impaired performance on maze and passive avoidance tests [89].

\subsection{GV and the Human Brain}

Whether the mechanisms identified in animal models associating glycemic variability with neuroinflammation translate into the human brain is not clear and few studies have directly investigated this question. However, there is evidence that glycemic variability may be associated with impairments in cognitive function as well as decreased recovery from CNS injury.

Amongst patients with T2DM, in studies measuring long-term GV most [90-92], but not all [93], studies have found that greater long-term GV is associated with cognitive deficits. One large-scale study of over 11,000 older patients observed no relationships between $\mathrm{HbA} 1 \mathrm{C}$, variability in $\mathrm{HbA} 1 \mathrm{C}$, c-reactive protein levels, and cognitive performance [93]; however, several other studies amongst healthy, older patients with T2DM and no history of cognitive dysfunction found that long-term GV was associated with lower metrics of cognitive function [90,91] as well as with decreased levels of limbic and temporal-parietal gray matter [92]. Moreover, in a large cohort of $>16,000$ older patients with T2DM followed prospectively, long-term variation in $\mathrm{HbA} 1 \mathrm{C}$ and variability in fasting plasma glucose levels was associated with an increased risk of developing Alzheimer's disease [94]. In more recent studies using continuous glucose monitoring, patients with T2DM with greater MAGE had worse performance on the Montreal Cognitive Assessment, Trail-Making Test-B, and the Verbal Fluency Test [95]. In participants studied in the Atherosclerosis Risk in Communities (ARIC) study with a 20-year follow-up, levels of 1,5-AG, a biological marker of postprandial glucose elevations, were significantly associated with the risk of developing dementia [96]. While most studies above involved older adults with T2DM, amongst children with T1DM, children with larger fluctuations in glucose levels were also noted to have poorer performance on cognitive tests, particularly related to memory [97]. Other studies have shown that antecedent hypoglycemic episodes in children may adversely impact performance on cognitive tasks $[98,99]$. Finally, even amongst individuals without diabetes, long-term GV is associated with poorer performance in memory recall and verbal fluency tests in older subjects [100,101].

GV-driven CNS inflammation may also play an important role in acute CNS injury. In a study of 417 participants with acute coronary syndrome (ACS), short-term GV, measured by the mean amplitude of glycemic excursion, was an independent predictor of subsequent adverse cardiovascular and cerebrovascular events [102]. Similarly, amongst patients hospitalized for ACS in the intensive care unit, the standard deviation of inpatient blood glucose measurements was the strongest predictor for 
subsequent major cardiovascular events [103]. Numerous studies have also reported that higher GV is associated with poor outcomes following stroke [104-106] including decreased functional outcomes at discharge [104], cognitive impairments post stroke [105], and increased 3-month mortality [106]. Finally, in a study of individuals with traumatic brain injury, increased GV was associated with poorer long-term neurological outcomes [107]. While the mechanisms underlying these associations remain unclear, strong evidence indicates that both hyper- and hypoglycemia contribute to the inflammatory state that occurs post-CNS injury [108].

\section{Strategies to Minimize GV}

At the time of writing, there are nearly 70 clinical trials specifically investigating the impact of glycemic variability on clinical outcomes [109]. With the widespread use of newer technologies such as continuous glucose monitors to measure short-term GV, more publications have concluded that GV is an additional source of diabetic complications independent of glycemic control. These publications have questioned the use of $\mathrm{HbA} 1 \mathrm{C}$ as the solo marker for diabetes treatment [110], evaluated the evidence from interventions to reduce GV [37], and proposed treatment plans that use GV as a component of diabetes management [111]. Both diabetes treatments and dietary choices have been found to reduce GV and the results of each will be explored here in turn.

\subsection{Therapeutic Interventions to Minimize GV}

Clinical studies have investigated the impact of both diabetes treatment factors as well as dietary factors that impact glycemic variability and several studies have indicated that reducing GV leads to a reduction in oxidative stress and a lower risk of developing diabetes-related complications. CGM use alone has been shown to improve glycemic control and minimizes glucose fluctuations [112,113]. In addition, studies on different modes of insulin administration have also shown that certain methods of administering insulin as treatment for T1DM achieve lower levels of GV. Continuous subcutaneous insulin infusion (CSII) has also been shown to achieve both better glycemic control and lower GV than multiple daily injection insulin administration [114]. Other treatment options available for diabetes control besides insulin have proven to be beneficial in reducing GV and inflammation including glucagon-like peptide-1 receptor antagonists (GLP-1 RA). One study found that use of the GLP1-RA, liraglutide, in conjunction with CGM in individuals with newly diagnosed T2DM improved not only glycemic control and glycemic variability, but also decreased oxidative stress markers [115]. Clinical trials with dipeptidyl peptidase 4 (DPP-4) inhibitors, which prevent the degradation of GLP1 have also been found to decrease MAGE as well as oxidative stress markers assessed by nitrotyrosine and inflammatory markers IL-6 and IL-18. Nitrotyrosine and IL-6 changes significantly correlated with changes in MAGE, but not in $\mathrm{HbA1c}$ [116]. Meglitinides, a class of antidiabetic agents which act on the KATP channels on pancreatic " $\beta$ " -cells to induce insulin release, can reduce postprandial glucose excursions and GV. These medications have also been shown to reduce peripheral oxidative stress markers including a regression of carotid intima-media thickness and a reduction in markers of systemic vascular inflammation in individuals with T2DM [117,118].

\subsection{Dietary Interventions to Minimize GV}

A large number of dietary variables have been shown to affect glucose fluctuations, including diet composition and meal timing. Evidence has shown that the type and quantity of carbohydrates has the greatest influence on glycemic response [119]. Lin et al. correlated dietary components with glucose fluctuations in individuals with T1DM. They found that the group with a carbohydrate intake of $<50 \%$ of their daily caloric intake had lower glucose fluctuations [120]. Other studies have shown that the supplementation of a high glycemic index meal with proteins such as whey protein reduces post meal glucoses by delaying gastric emptying, stimulating insulin and incretin secretion [121]. A study performed in subjects with obesity, in which two hypocaloric diets with similar macronutrient composition but different glycemic index were given, showed that adherence to a low glycemic index 
hypocaloric diet led to lower levels of GV as well as improved endothelial function when compared to high glycemic index foods [122]. Other studies have shown that the addition of certain ingredients can reduce glycemic response of foods. As an example, Henry et al. provided a low glycemic index (isomaltose) and high glycemic index (sucrose) diet to healthy men in a randomized, double-blind, controlled crossover design. The low glycemic index diet resulted in lower glycemic variability measured by CGM [123].

The order of food intake may also impact postprandial glucose levels. Shukla et al. showed that the temporal sequence of carbohydrate ingestion during a meal has a significant impact on postprandial glucose and insulin excursions [124]. Individuals were given identical meals of fixed portions of carbohydrates and protein but in a different order. Individuals who consumed the carbohydrates first were noted to have higher postprandial glucose excursions compared to those who had the protein component first [124]. In patients with type 2 diabetes, skipping breakfast has also been found to lead to higher GV. Subjects skipping breakfast had a lower fiber intake and higher carbohydrate-to-fiber ratio than those eating breakfast. While total calories per day were equal between the groups, omission of breakfast was associated with higher postprandial glucose responses after lunch and dinner, which may be mediated by lower glucagon-like peptide 1 and insulin secretion [125]. Finally, in a within-subject analysis study of women with gestational diabetes mellitus, high carbohydrate morning meals also had higher measures of MAGE but lower mean glucose compared to equicaloric diets that distributed carbohydrates throughout the day [126].

\section{Conclusions}

There is increasing evidence that glycemic variability is an independent driver of increased oxidative stress and inflammation, which can be particularly detrimental to CNS function. With greater use of technologies such as CGMs, which will allow for more rigorous quantifications of GV, future studies will be needed to define the exact relationships between GV, inflammation, and brain function.

Author Contributions: Investigation, C.W., J.J.H. and E.S.-R; writing-original draft preparation, review, and editing, C.W., J.J.H. and E.S.-R.; funding acquisition, J.J.H. and E.S.-R. All authors have read and agreed to the published version of the manuscript.

Funding: This publication was made possible by the National Institute of Health (NIH) and National Institute of Diabetes and Digestive and Kidney Disease, grant numbers DK020495 and DK123227; and CTSA Grant number KL2TR001962 from the National Center for Advancing Translational Science (NCATS), components of the NIH, and NIH roadmap for Medical Research. Its contents are solely the responsibility of the authors and do not necessarily represent the official view of NIH.

Conflicts of Interest: The authors declare no conflict of interest.

\section{References}

1. Mergenthaler, P.; Lindauer, U.; Dienel, G.A.; Meisel, A. Sugar for the brain: The role of glucose in physiological and pathological brain function. Trends Neurosci. 2013, 36, 587-597. [CrossRef]

2. Berg, J.M.; Tymoczko, J.L.; Stryer, L. Biochemistry; W.H. Freeman: Basingstoke, UK, 2012.

3. Brownlee, M. The pathobiology of diabetic complications: A unifying mechanism. Diabetes 2005, 54, 1615-1625. [CrossRef]

4. Mittal, M.; Siddiqui, M.R.; Tran, K.; Reddy, S.P.; Malik, A.B. Reactive oxygen species in inflammation and tissue injury. Antioxid. Redox Signal. 2014, 20, 1126-1167. [CrossRef] [PubMed]

5. Luc, K.; Schramm-Luc, A.; Guzik, T.J.; Mikołajczyk, T.P. Oxidative stress and inflammatory markers in prediabetes and diabetes. J. Physiol. Pharmacol. 2019, 70. [CrossRef]

6. Isaev, N.K.; Stel'mashuk, E.V.; Zorov, D.B. Cellular mechanisms of brain hypoglycemia. Biochemistry 2007, 72, 471-478. [CrossRef]

7. Nusca, A.; Tuccinardi, D.; Albano, M.; Cavallaro, C.; Ricottini, E.; Manfrini, S.; Pozzilli, P.; Di Sciascio, G. Glycemic variability in the development of cardiovascular complications in diabetes. Diabetes Metab. Res. Rev. 2018, 34, e3047. [CrossRef] [PubMed] 
8. Echouffo-Tcheugui, J.B.; Zhao, S.; Brock, G.; Matsouaka, R.A.; Kline, D.; Joseph, J.J. Visit-to-Visit Glycemic Variability and Risks of Cardiovascular Events and All-Cause Mortality: The ALLHAT Study. Diabetes Care 2019, 42, 486-493. [CrossRef] [PubMed]

9. Zhou, J.J.; Schwenke, D.C.; Bahn, G.; Reaven, P. Glycemic Variation and Cardiovascular Risk in the Veterans Affairs Diabetes Trial. Diabetes Care 2018, 41, 2187-2194. [CrossRef]

10. Gross, T.M.; Bode, B.W.; Einhorn, D.; Kayne, D.M.; Reed, J.H.; White, N.H.; Mastrototaro, J.J. Performance evaluation of the MiniMed continuous glucose monitoring system during patient home use. Diabetes Technol. Ther. 2000, 2, 49-56. [CrossRef]

11. Rodbard, D. Interpretation of continuous glucose monitoring data: Glycemic variability and quality of glycemic control. Diabetes Technol. Ther. 2009, 11 (Suppl. 1), S55-S67. [CrossRef]

12. Umpierrez, G.E.; Kovatchev, B.P. Glycemic Variability: How to Measure and Its Clinical Implication for Type 2 Diabetes. Am. J. Med. Sci. 2018, 356, 518-527. [CrossRef] [PubMed]

13. Diabetes Control and Complications Trial Research Group; Nathan, D.M.; Genuth, S.; Lachin, J.; Cleary, P.; Crofford, O.; Davis, M.; Rand, L.; Siebert, C. The effect of intensive treatment of diabetes on the development and progression of long-term complications in insulin-dependent diabetes mellitus. N. Engl. J. Med. 1993, 329, 977-986. [PubMed]

14. Anonymous. Intensive blood-glucose control with sulphonylureas or insulin compared with conventional treatment and risk of complications in patients with type 2 diabetes (UKPDS 33). UK Prospective Diabetes Study (UKPDS) Group. Lancet 1998, 352, 837-853. [CrossRef]

15. Bunn, H.F.; Haney, D.N.; Kamin, S.; Gabbay, K.H.; Gallop, P.M. The biosynthesis of human hemoglobin A1c. Slow glycosylation of hemoglobin in vivo. J. Clin. Investig. 1976, 57, 1652-1659. [CrossRef]

16. Kohnert, K.D.; Heinke, P.; Vogt, L.; Zander, E.; Fritzsche, G.; Augstein, P.; Salzsieder, E. Reduced Glucose Variability Is Associated With Improved Quality of Glycemic Control in Patients With Type 2 Diabetes: A 12-Month Observational Study. J. Endocrinol. Metab. 2011, 2011. [CrossRef]

17. Rodriguez-Gutierrez, R.; Gonzalez-Gonzalez, J.G.; A Zuñiga-Hernandez, J.; McCoy, R.G. Benefits and harms of intensive glycemic control in patients with type 2 diabetes. BMJ 2019, 367, 15887. [CrossRef]

18. Kim, M.J.; Jung, H.S.; Hwang-Bo, Y.; Cho, S.W.; Jang, H.C.; Kim, S.Y.; Park, K.S. Evaluation of 1,5-anhydroglucitol as a marker for glycemic variability in patients with type 2 diabetes mellitus. Acta Diabetol. 2013, 50, 505-510. [CrossRef]

19. Chan, C.L.; Pyle, L.; Kelsey, M.M.; Newnes, L.; Baumgartner, A.; Zeitler, P.S.; Nadeau, K.J. Alternate glycemic markers reflect glycemic variability in continuous glucose monitoring in youth with prediabetes and type 2 diabetes. Pediatr. Diabetes 2017, 18, 629-636. [CrossRef]

20. West, A.P.; Shadel, G.S.; Ghosh, S. Mitochondria in innate immune responses. Nat. Rev. Immunol. 2011, 11, 389-402. [CrossRef]

21. Schieber, M.; Chandel, N.S. ROS function in redox signaling and oxidative stress. Curr. Biol. 2014, 24, R453-R462. [CrossRef]

22. Sango, K.; Suzuki, T.; Yanagisawa, H.; Takaku, S.; Hirooka, H.; Tamura, M.; Watabe, K. High glucose-induced activation of the polyol pathway and changes of gene expression profiles in immortalized adult mouse Schwann cells IMS32. J. Neurochem. 2006, 98, 446-458. [CrossRef] [PubMed]

23. Lee, A.Y.; Chung, S.S. Contributions of polyol pathway to oxidative stress in diabetic cataract. FASEB J. 1999, 13, 23-30. [CrossRef] [PubMed]

24. Horal, M.; Zhang, Z.; Stanton, R.; Virkamäki, A.; Loeken, M.R. Activation of the hexosamine pathway causes oxidative stress and abnormal embryo gene expression: Involvement in diabetic teratogenesis. Birth Defects Res. A Clin. Mol. Teratol. 2004, 70, 519-527. [CrossRef] [PubMed]

25. Kolm-Litty, V.; Sauer, U.; Nerlich, A.; Lehmann, R.; Schleicher, E.D. High glucose-induced transforming growth factor beta1 production is mediated by the hexosamine pathway in porcine glomerular mesangial cells. J. Clin. Investig. 1998, 101, 160-169. [CrossRef]

26. Ghelani, H.; Razmovski-Naumovski, V.; Pragada, R.R.; Nammi, S. Attenuation of Glucose-Induced Myoglobin Glycation and the Formation of Advanced Glycation End Products (AGEs) by (R)- $\alpha$-Lipoic Acid In Vitro. Biomolecules 2018, 8, 9. [CrossRef]

27. Degenhardt, T.P.; Thorpe, S.R.; Baynes, J.W. Chemical modification of proteins by methylglyoxal. Cell. Mol. Biol. 1998, 44, 1139-1145. 
28. Miele, C.; Paturzo, F.; Teperino, R.; Sakane, F.; Fiory, F.; Oriente, F.; Ungaro, P.; Valentino, R.; Beguinot, F.; Formisano, P. Glucose regulates diacylglycerol intracellular levels and protein kinase $C$ activity by modulating diacylglycerol kinase subcellular localization. J. Biol. Chem. 2007, 282, 31835-31843. [CrossRef]

29. Koya, D.; King, G.L. Protein kinase C activation and the development of diabetic complications. Diabetes 1998, 47, 859-866. [CrossRef]

30. Brownlee, M. Biochemistry and molecular cell biology of diabetic complications. Nature 2001, 414, 813-820. [CrossRef]

31. Bhardwaj, S.K.; Sharma, M.L.; Gulati, G.; Chhabra, A.; Kaushik, R.; Sharma, P.; Kaur, G. Effect of starvation and insulin-induced hypoglycemia on oxidative stress scavenger system and electron transport chain complexes from rat brain, liver, and kidney. Mol. Chem. Neuropathol. 1998, 34, 157-168. [CrossRef]

32. Cardoso, S.; Santos, M.S.; Seiça, R.; Moreira, P.I. Cortical and hippocampal mitochondria bioenergetics and oxidative status during hyperglycemia and/or insulin-induced hypoglycemia. Biochim. Biophys. Acta 2010, 1802, 942-951. [CrossRef] [PubMed]

33. Cardoso, S.; Santos, R.X.; Correia, S.C.; Carvalho, C.; Santos, M.S.; Baldeiras, I.; Oliveira, C.R.; Moreira, P.I. Insulin-induced recurrent hypoglycemia exacerbates diabetic brain mitochondrial dysfunction and oxidative imbalance. Neurobiol. Dis. 2013, 49,1-12. [CrossRef] [PubMed]

34. McNeilly, A.D.; Gallagher, J.R.; Dinkova-Kostova, A.T.; Hayes, J.D.; Sharkey, J.; Ashford, M.L.J.; McCrimmon, R.J. Nrf2-Mediated Neuroprotection Against Recurrent Hypoglycemia Is Insufficient to Prevent Cognitive Impairment in a Rodent Model of Type 1 Diabetes. Diabetes 2016, 65, 3151-3160. [CrossRef][PubMed]

35. Kahal, H.; Halama, A.; Aburima, A.; Bhagwat, A.M.; Butler, A.E.; Graumann, J.; Suhre, K.; Sathyapalan, T.; Atkin, S.L. Effect of induced hypoglycemia on inflammation and oxidative stress in type 2 diabetes and control subjects. Sci. Rep. 2020, 10, 4750. [CrossRef]

36. Monnier, L.; Mas, E.; Ginet, C.; Michel, F.; Villon, L.; Cristol, J.-P.; Colette, C. Activation of oxidative stress by acute glucose fluctuations compared with sustained chronic hyperglycemia in patients with type 2 diabetes. JAMA 2006, 295, 1681-1687. [CrossRef]

37. Ceriello, A.; Monnier, L.; Owens, D. Glycaemic variability in diabetes: Clinical and therapeutic implications. Lancet Diabetes Endocrinol. 2019, 7, 221-230. [CrossRef]

38. The Diabetes Control and Complications Trial Research Group. The relationship of glycemic exposure ( $\mathrm{HbA1c}$ ) to the risk of development and progression of retinopathy in the diabetes control and complications trial. Diabetes 1995, 44, 968-983. [CrossRef]

39. Hirsch, I.B.; Brownlee, M. Should minimal blood glucose variability become the gold standard of glycemic control? J. Diabetes Its Complicat. 2005, 19, 178-181. [CrossRef]

40. Hirsch, I.B. Glycemic variability: It's not just about A1C anymore! Diabetes Technol. Ther. 2005, 7, 780-783. [CrossRef]

41. Wentholt, I.M.E.; Kulik, W.; Michels, R.P.J.; Hoekstra, J.B.L.; Devries, J.H. Glucose fluctuations and activation of oxidative stress in patients with type 1 diabetes. Diabetologia 2008, 51, 183. [CrossRef]

42. Siegelaar, S.E.; Barwari, T.; Kulik, W.; Hoekstra, J.B.; Devries, J.H. No relevant relationship between glucose variability and oxidative stress in well-regulated type 2 diabetes patients. J. Diabetes Sci. Technol. 2011, 5, 86-92. [CrossRef] [PubMed]

43. Kohata, Y.; Ohara, M.; Nagaike, H.; Fujikawa, T.; Osaka, N.; Goto, S.; Fukase, A.; Kushima, H.; Hiromura, M.; Terasaki, M.; et al. Association of Hemoglobin A1c, 1,5-Anhydro-d-Glucitol and Glycated Albumin with Oxidative Stress in Type 2 Diabetes Mellitus Patients: A Cross-Sectional Study. Diabetes Ther. 2020, 11, 655-665. [CrossRef]

44. Ohara, M.; Nagaike, H.; Goto, S.; Fukase, A.; Tanabe, Y.; Tomoyasu, M.; Yamamoto, T.; Hayashi, T.; Fukui, T.; Hirano, T. Improvements of ambient hyperglycemia and glycemic variability are associated with reduction in oxidative stress for patients with type 2 diabetes. Diabetes Res. Clin. Pract. 2018, 139, 253-261. [CrossRef] [PubMed]

45. Nalysnyk, L.; Hernandez-Medina, M.; Krishnarajah, G. Glycaemic variability and complications in patients with diabetes mellitus: Evidence from a systematic review of the literature. Diabetes Obes. Metab. 2010, 12, 288-298. [CrossRef]

46. Siegelaar, S.E.; Holleman, F.; Hoekstra, J.B.L.; Devries, J.H. Glucose variability; does it matter? Endocr. Rev. 2010, 31, 171-182. [CrossRef] 
47. Danne, T.; Nimri, R.; Battelino, T.; Bergenstal, R.M.; Close, K.L.; DeVries, J.H.; Garg, S.; Heinemann, L.; Hirsch, I.; Amiel, S.A.; et al. International Consensus on Use of Continuous Glucose Monitoring. Diabetes Care 2017, 40, 1631-1640. [CrossRef]

48. Moheet, A.; Mangia, S.; Seaquist, E.R. Impact of diabetes on cognitive function and brain structure. Ann. N. Y. Acad. Sci. 2015, 1353, 60-71. [CrossRef]

49. Evans, M.L.; Sherwin, R.S. Blood glucose and the brain in diabetes: Between a rock and a hard place? Curr. Diabetes Rep. 2002, 2, 101-102. [CrossRef]

50. Hayden, M.R. Type 2 Diabetes Mellitus Increases the Risk of Late-Onset Alzheimer's Disease: Ultrastructural Remodeling of the Neurovascular Unit and Diabetic Gliopathy. Brain Sci. 2019, 9, 262. [CrossRef]

51. Machida, T.; Takata, F.; Matsumoto, J.; Miyamura, T.; Hirata, R.; Kimura, I.; Kataoka, Y.; Dohgu, S.; Yamauchi, A. Contribution of thrombin-reactive brain pericytes to blood-brain barrier dysfunction in an in vivo mouse model of obesity-associated diabetes and an in vitro rat model. PLoS ONE 2017, 12, e0177447. [CrossRef]

52. Yatomi, Y.; Tanaka, R.; Shimada, Y.; Yamashiro, K.; Liu, M.; Mitome-Mishima, Y.; Miyamoto, N.; Ueno, Y.; Urabe, T.; Hattori, N. Type 2 diabetes reduces the proliferation and survival of oligodendrocyte progenitor cells in ishchemic white matter lesions. Neuroscience 2015, 289, 214-223. [CrossRef] [PubMed]

53. Huang, Y.; Liao, Z.; Lin, X.; Wu, X.; Chen, X.; Bai, X.; Zhuang, Y.; Yang, Y.; Zhang, J. Overexpression of miR-146a Might Regulate Polarization Transitions of BV-2 Cells Induced by High Glucose and Glucose Fluctuations. Front. Endocrinol. 2019, 10, 719. [CrossRef]

54. Hawkins, B.T.; Lundeen, T.F.; Norwood, K.M.; Brooks, H.L.; Egleton, R.D. Increased blood-brain barrier permeability and altered tight junctions in experimental diabetes in the rat: Contribution of hyperglycaemia and matrix metalloproteinases. Diabetologia 2007, 50, 202-211. [CrossRef] [PubMed]

55. Hawkins, B.T.; Lundeen, T.F.; Norwood, K.M.; Brooks, H.L.; Egleton, R.D. Blood-Brain Barrier Disruption and Neurovascular Unit Dysfunction in Diabetic Mice: Protection with the Mitochondrial Carbonic Anhydrase Inhibitor Topiramate. J. Pharmacol. Exp. Ther. 2016, 359, 452.

56. Halvorson, B.D.; Whitehead, S.N.; McGuire, J.J.; Wiseman, R.W.; Frisbee, J.C. Endothelium-dependent impairments to cerebral vascular reactivity with type 2 diabetes mellitus in the Goto-Kakizaki rat. Am. J. Physiol. Regul. Integr. Comp. Physiol. 2019, 317, R149-R159. [CrossRef] [PubMed]

57. Li, W.; RMaloney, E.; Aw, T.Y. High glucose, glucose fluctuation and carbonyl stress enhance brain microvascular endothelial barrier dysfunction: Implications for diabetic cerebral microvasculature. Redox Biol. 2015, 5, 80-90. [CrossRef]

58. Sajja, R.K.; Cucullo, L. Altered glycaemia differentially modulates efflux transporter expression and activity in hCMEC/D3 cell line. Neurosci. Lett. 2015, 598, 59-65. [CrossRef] [PubMed]

59. El-Osta, A.; Brasacchio, D.; Yao, D.; Pocai, A.; Jones, P.L.; Roeder, R.G.; Cooper, M.E.; Brownlee, M. Transient high glucose causes persistent epigenetic changes and altered gene expression during subsequent normoglycemia. J. Exp. Med. 2008, 205, 2409-2417. [CrossRef]

60. Schisano, B.; Tripathi, G.; McGee, K.; McTernan, P.G.; Ceriello, A. Glucose oscillations, more than constant high glucose, induce p53 activation and a metabolic memory in human endothelial cells. Diabetologia 2011, 54, 1219-1226. [CrossRef]

61. Risso, A.; Mercuri, F.; Quagliaro, L.; Damante, G.; Ceriello, A. Intermittent high glucose enhances apoptosis in human umbilical vein endothelial cells in culture. Am. J. Physiol. Endocrinol. Metab. 2001, 281, E924-E930. [CrossRef]

62. Rom, S.; Zuluaga-Ramirez, V.; Gajghate, S.; Seliga, A.; Winfield, M.; Heldt, N.A.; Kolpakov, M.A.; Bashkirova, Y.V.; Sabri, A.K.; Persidsky, Y. Hyperglycemia-driven neuroinflammation compromises BBB leading to memory loss in both diabetes mellitus (DM) type 1 and type 2 mouse models. Mol. Neurobiol. 2019, 56, 1883-1896. [CrossRef] [PubMed]

63. Simpson, I.A.; Appel, N.M.; Hokari, M.; Oki, J.; Holman, G.D.; Maher, F.; Koehler-Stec, E.M.; Vannucci, S.J.; Smith, Q.R. Blood-Brain Barrier Glucose Transporter: Effects of Hypo-and Hyperglycemia Revisited. J. Neurochem. 1999, 72, 238-247. [CrossRef] [PubMed]

64. Kumagai, A.K.; Kang, Y.S.; Boado, R.J.; Pardridge, W.M. Upregulation of blood-brain barrier GLUT1 glucose transporter protein and mRNA in experimental chronic hypoglycemia. Diabetes 1995, 44, 1399-1404. [CrossRef] [PubMed] 
65. Duelli, R.; Maurer, M.H.; Staudt, R.; Heiland, S.; Duembgen, L.; Kuschinsky, W. Increased cerebral glucose utilization and decreased glucose transporter Glut1 during chronic hyperglycemia in rat brain. Brain Res. 2000, 858, 338-347. [CrossRef]

66. Hwang, J.J.; Jiang, L.; Hamza, M.; Rangel, E.S.; Dai, F.; Belfort-DeAguiar, R.; Parikh, L.; Koo, B.B.; Rothman, D.L.; Mason, G.; et al. Blunted rise in brain glucose levels during hyperglycemia in adults with obesity and T2DM. JCI Insight 2017, 2, e95913. [CrossRef]

67. Seaquist, E.R.; Tkáč, I.; Damberg, G.; Thomas, W.; Gruetter, R. Brain glucose concentrations in poorly controlled diabetes mellitus as measured by high-field magnetic resonance spectroscopy. Metabolism 2005, 54, 1008-1013. [CrossRef]

68. Hwang, J.J.; Jiang, L.; Rangel, E.S.; Fan, X.; Ding, Y.; Lam, W.; Leventhal, J.; Dai, F.; Rothman, D.L.; Mason, G.F.; et al. Glycemic Variability and Brain Glucose Levels in Type 1 Diabetes. Diabetes 2019, 68, 163-171. [CrossRef]

69. Ceriello, A.; Esposito, K.; Ihnat, M.; Thorpe, J.; Giugliano, D. Effect of acute hyperglycaemia, long-term glycaemic control and insulin on endothelial dysfunction and inflammation in Type 1 diabetic patients with different characteristics. Diabet. Med. 2010, 27, 911-917. [CrossRef]

70. Ceriello, A.; Esposito, K.; Piconi, L.; Ihnat, M.A.; Thorpe, J.E.; Testa, R.; Boemi, M.; Giugliano, D. Oscillating glucose is more deleterious to endothelial function and oxidative stress than mean glucose in normal and type 2 diabetic patients. Diabetes 2008, 57, 1349-1354. [CrossRef]

71. Ceriello, A.; Novials, A.; Ortega, E.; La Sala, L.; Pujadas, G.; Testa, R.; Bonfigli, A.R.; Esposito, K.; Giugliano, D. Evidence that hyperglycemia after recovery from hypoglycemia worsens endothelial function and increases oxidative stress and inflammation in healthy control subjects and subjects with type 1 diabetes. Diabetes 2012, 61, 2993-2997. [CrossRef]

72. Costantino, S.; Paneni, F.; Battista, R.; Castello, L.; Capretti, G.; Chiandotto, S.; Tanese, L.; Russo, G.; Pitocco, D.; Lanza, G.A.; et al. Impact of glycemic variability on chromatin remodeling, oxidative stress, and endothelial dysfunction in patients with type 2 diabetes and with target HbA1c levels. Diabetes 2017, 66, 2472-2482. [CrossRef] [PubMed]

73. Maiorino, M.I.; Casciano, O.; Della Volpe, E.; Bellastella, G.; Giugliano, D.; Esposito, K. Reducing glucose variability with continuous subcutaneous insulin infusion increases endothelial progenitor cells in type 1 diabetes: An observational study. Endocrine 2016, 52, 244-252. [CrossRef] [PubMed]

74. Lawson, L.J.; Perry, V.H.; Gordon, S. Turnover of resident microglia in the normal adult mouse brain. Neuroscience 1992, 48, 405-415. [CrossRef]

75. Schafer, D.P.; Lehrman, E.K.; Kautzman, A.G.; Koyama, R.; Mardinly, A.R.; Yamasaki, R.; Ransohoff, R.M.; Greenberg, M.E.; Barres, B.A.; Stevens, B. Microglia sculpt postnatal neural circuits in an activity and complement-dependent manner. Neuron 2012, 74, 691-705. [CrossRef]

76. Paolicelli, R.C.; Bolasco, G.; Pagani, F.; Maggi, L.; Scianni, M.; Panzanelli, P.; Giustetto, M.; Ferreira, T.A.; Guiducci, E.; Dumas, L.; et al. Synaptic pruning by microglia is necessary for normal brain development. Science 2011, 333, 1456-1458. [CrossRef]

77. Paolicelli, R.C.; Gross, C.T. Microglia in development: Linking brain wiring to brain environment. Neuron Glia Biol. 2011, 7, 77-83. [CrossRef]

78. Arandjelovic, S.; Ravichandran, K.S. Phagocytosis of apoptotic cells in homeostasis. Nat. Immunol. 2015, 16, 907-917. [CrossRef]

79. Ponomarev, E.D.; Veremeyko, T.; Barteneva, N.; Krichevsky, A.M.; Weiner, H.L. MicroRNA-124 promotes microglia quiescence and suppresses EAE by deactivating macrophages via the C/EBP- $\alpha$-PU.1 pathway. Nat. Med. 2011, 17, 64-70. [CrossRef]

80. van Gool, W.A.; van de Beek, D.; Eikelenboom, P. Systemic infection and delirium: When cytokines and acetylcholine collide. Lancet 2010, 375, 773-775. [CrossRef]

81. Block, M.L.; Zecca, L.; Hong, J.S. Microglia-mediated neurotoxicity: Uncovering the molecular mechanisms. Nat. Rev. Neurosci. 2007, 8, 57-69. [CrossRef]

82. McNally, L.; Bhagwagar, Z.; Hannestad, J. Inflammation, glutamate, and glia in depression: A literature review. CNS Spectr. 2008, 13, 501-510. [CrossRef] [PubMed]

83. Yakovleva, T.; Bazov, I.; Watanabe, H.; Hauser, K.F.; Bakalkin, G. Transcriptional control of maladaptive and protective responses in alcoholics: A role of the NF-kB system. Brain Behav. Immun. 2011, 25 (Suppl. 1), S29-S38. [CrossRef] [PubMed] 
84. Chen, C.; Wu, S.; Hong, Z.; Chen, X.; Shan, X.; Fischbach, S.; Xiao, X. Chronic hyperglycemia regulates microglia polarization through ERK5. Aging 2019, 11, 697-706. [CrossRef] [PubMed]

85. Hsieh, C.-F.; Liu, C.-K.; Lee, C.-T.; Yu, L.-E.; Wang, J.-Y. Acute glucose fluctuation impacts microglial activity, leading to inflammatory activation or self-degradation. Sci. Rep. 2019, 9, 1-16. [CrossRef]

86. Russo, V.C.; Higgins, S.; Werther, G.A.; Cameron, F. Effects of fluctuating glucose levels on neuronal cells in vitro. Neurochem. Res. 2012, 37, 1768-1782. [CrossRef]

87. Quincozes-Santos, A.; Bobermin, L.D.; De Assis, A.M.; Gonçalves, C.-A.; Souza, D.O. Fluctuations in glucose levels induce glial toxicity with glutamatergic, oxidative and inflammatory implications. Biochim. Biophys. Acta Mol. Basis Dis. 2017, 1863, 1-14. [CrossRef]

88. Wang, H.; Deng, J.; Chen, L.; Ding, K.; Wang, Y. Acute glucose fluctuation induces inflammation and neurons apoptosis in hippocampal tissues of diabetic rats. J. Cell. Biochem. 2019. [CrossRef]

89. Wang, H.; Deng, J.; Chen, L.; Ding, K.; Wang, Y. The mechanisms of glycemic variability accelerate diabetic central neuropathy and diabetic peripheral neuropathy in diabetic rats. Biochem. Biophys. Res. Commun. 2019, 510, 35-41.

90. Minami, T.; Ito, Y.; Yamada, M.; Furuta, R.; Minagawa, F.; Kamata, K.; Kameda, A.; Terauchi, Y. The effect of long-term past glycemic control on executive function among patients with type 2 diabetes mellitus. Diabetol. Int. 2020, 11, 114-120. [CrossRef]

91. Kim, C.; Sohn, J.-H.; Jang, M.U.; Kim, S.-H.; Choi, M.-G.; Ryu, O.-H.; Lee, S.; Choi, H.-C. Association between visit-to-visit glucose variability and cognitive function in aged type 2 diabetic patients: A cross-sectional study. PLoS ONE 2015, 10, e0132118. [CrossRef]

92. Cui, X.; Abduljalil, A.; Manor, B.D.; Peng, C.-K.; Novak, V. Multi-scale glycemic variability: A link to gray matter atrophy and cognitive decline in type 2 diabetes. PLOS ONE 2014, 9, e86284. [CrossRef] [PubMed]

93. Akrivos, J.; Ravona-Springer, R.; Schmeidler, J.; Leroith, D.; Heymann, A.; Preiss, R.; Hoffman, H.; Koifman, K.; Silverman, J.M.; Beeri, M.S. Glycemic control, inflammation, and cognitive function in older patients with type 2 diabetes. Int. J. Geriatr. Psychiatry 2015, 30, 1093-1100. [CrossRef] [PubMed]

94. Li, T.-C.; Yang, C.-P.; Tseng, S.-T.; Li, C.-I.; Liu, C.-S.; Lin, W.-Y.; Hwang, K.-L.; Yang, S.-Y.; Chiang, J.-H.; Lin, C. Visit-to-Visit Variations in Fasting Plasma Glucose and $\mathrm{HbA}(1 \mathrm{c})$ Associated With an Increased Risk of Alzheimer Disease: Taiwan Diabetes Study. Diabetes Care 2017, 40, 1210-1217. [CrossRef] [PubMed]

95. Xia, W.; Luo, Y.; Chen, Y.-C.; Chen, H.; Ma, J.; Yin, X. Glucose Fluctuations Are Linked to Disrupted Brain Functional Architecture and Cognitive Impairment. J. Alzheimer's Dis. 2020, 1-11. [CrossRef] [PubMed]

96. Rawlings, A.M.; Sharrett, A.R.; Mosley, T.H.; Ballew, S.H.; Deal, J.A.; Selvin, E. Glucose Peaks and the Risk of Dementia and 20-Year Cognitive Decline. Diabetes Care 2017, 40, 879-886. [CrossRef]

97. He, J.; Ryder, A.G.; Li, S.; Liu, W.; Zhu, X. Glycemic extremes are related to cognitive dysfunction in children with type 1 diabetes: A meta-analysis. J. Diabetes Investig. 2018, 9, 1342-1353. [CrossRef]

98. Chaytor, N.S.; Barbosa-Leiker, C.; Ryan, C.M.; Germine, L.T.; Hirsch, I.B.; Weinstock, R.S. Clinically significant cognitive impairment in older adults with type 1 diabetes. J. Diabetes Its Complicat. 2019, 33, 91-97. [CrossRef]

99. Knight, M.F.; Perfect, M.M. Glycemic control influences on academic performance in youth with Type 1 diabetes. Sch. Psychol. 2019, 34, 646. [CrossRef]

100. Yu, Z.; Zhu, Y.; Li, D.; Wu, M.-Y.; Tang, M.-L.; Wang, J.; Chen, K. Association between visit-to-visit variability of $\mathrm{HbA} 1 \mathrm{c}$ and cognitive decline: A pooled analysis of two prospective population-based cohorts. Diabetologia 2020, 63, 85-94. [CrossRef]

101. Bancks, M.; Carnethon, M.R.; Jacobs, D.R.; Launer, L.J.; Reis, J.; Schreiner, P.J.; Shah, R.V.; Sidney, S.; Yaffe, K.; Yano, Y.; et al. Fasting Glucose Variability in Young Adulthood and Cognitive Function in Middle Age: The Coronary Artery Risk Development in Young Adults (CARDIA) Study. Diabetes Care 2018, 41, 2579-2585. [CrossRef]

102. Takahashi, H.; Iwahashi, N.; Kirigaya, J.; Kataoka, S.; Minamimoto, Y.; Gohbara, M.; Abe, T.; Okada, K.; Matsuzawa, Y.; Konishi, M.; et al. Glycemic variability determined with a continuous glucose monitoring system can predict prognosis after acute coronary syndrome. Cardiovasc. Diabetol. 2018, 17, 116. [CrossRef] [PubMed]

103. Gerbaud, E.; Darier, R.; Montaudon, M.; Beauvieux, M.-C.; Coffin-Boutreux, C.; Coste, P.; Douard, H.; Ouattara, A.; Catargi, B. Glycemic Variability Is a Powerful Independent Predictive Factor of Midterm Major Adverse Cardiac Events in Patients With Diabetes With Acute Coronary Syndrome. Diabetes Care 2019, 42, 674-681. [CrossRef] [PubMed] 
104. Camara-Lemarroy, C.; González-Moreno, E.; Garza-Villarreal, E.; Treviño-Herrera, A.; Tena-Montiel, R.; Muruet, W.; Rivera, J.G. Glycemic Variability and Functional Outcome after Acute Ischemic Stroke (P1.191); AAN Enterprises: Minneapolis, MN, USA, 2016.

105. Lim, J.-S.; Kim, C.; Oh, M.S.; Lee, J.-H.; Jung, S.; Sohn, J.-H.; Lee, S.-H.; Kim, Y.J.; Kim, Y.; Suh, S.W.; et al. Effects of glycemic variability and hyperglycemia in acute ischemic stroke on post-stroke cognitive impairments. J. Diabetes Its Complicat. 2018, 32, 682-687. [CrossRef]

106. Wada, S.; Yoshimura, S.; Inoue, M.; Matsuki, T.; Arihiro, S.; Koga, M.; Kitazono, T.; Makino, H.; Hosoda, K.; Ihara, M.; et al. Outcome Prediction in Acute Stroke Patients by Continuous Glucose Monitoring. J. Am. Heart Assoc. 2018, 7. [CrossRef]

107. Matsushima, K.; Peng, M.; Velasco, C.; Schaefer, E.; Diaz-Arrastia, R.; Frankel, H. Glucose variability negatively impacts long-term functional outcome in patients with traumatic brain injury. J. Crit. Care 2012, 27, 125-131. [CrossRef]

108. Robbins, N.M.; Swanson, R.A. Opposing effects of glucose on stroke and reperfusion injury: Acidosis, oxidative stress, and energy metabolism. Stroke 2014, 45, 1881-1886. [CrossRef]

109. ClinicalTrials.gov. U.S. National Library of Medicine. Available online: https://www.clinicaltrials.gov. (accessed on 19 December 2020).

110. Ceriello, A. Glycemic variability, persistent oxidative stress, and diabetic complications. Medicographa 2017, 39, 233-236.

111. Ceriello, A. Glucose variability and diabetic complications: Is it time to treat? Diabetes Care 2020, 43, 1169-1171. [CrossRef] [PubMed]

112. El-Laboudi, A.H.; Godsland, I.F.; Johnston, D.G.; Oliver, N. Measures of Glycemic Variability in Type 1 Diabetes and the Effect of Real-Time Continuous Glucose Monitoring. Diabetes Technol. Ther. 2016, 18, 806-812. [CrossRef] [PubMed]

113. Bolinder, J.; Antuna, R.; Geelhoed-Duijvestijn, P.; Kröger, J.; Weitgasser, R. Novel glucose-sensing technology and hypoglycaemia in type 1 diabetes: A multicentre, non-masked, randomised controlled trial. Lancet 2016, 388, 2254-2263. [CrossRef]

114. Bruttomesso, D.; Crazzolara, D.; Maran, A.; Costa, S.; Pos, M.D.; Girelli, A.; Lepore, G.; Aragona, M.; Iori, E.; Valentini, U.; et al. In Type 1 diabetic patients with good glycaemic control, blood glucose variability is lower during continuous subcutaneous insulin infusion than during multiple daily injections with insulin glargine. Diabet. Med. 2008, 25, 326-332. [CrossRef] [PubMed]

115. Li, L.-Q.; Yao, M.-Y.; Ma, J.-X.; Xue, P.; Li, Y.-K. Continuous subcutaneous insulin infusion combined with liraglutide reduced glycemic variability and oxidative stress in type 2 diabetes mellitus: A study based on the flash glucose monitoring system. Endocr. J. 2019, 66, 871-880. [CrossRef] [PubMed]

116. Rizzo, M.R.; Barbieri, M.; Marfella, R.; Paolisso, G. Reduction of oxidative stress and inflammation by blunting daily acute glucose fluctuations in patients with type 2 diabetes: Role of dipeptidyl peptidase-IV inhibition. Diabetes Care 2012, 35, 2076-2082. [CrossRef]

117. Esposito, K.; Giugliano, D.; Nappo, F.; Marfella, R. Regression of carotid atherosclerosis by control of postprandial hyperglycemia in type 2 diabetes mellitus. Circulation 2004, 110, 214-219. [CrossRef] [PubMed]

118. Kodani, N.; Saisho, Y.; Tanaka, K.; Kawai, T.; Itoh, H. Effects of mitiglinide, a short-acting insulin secretagogue, on daily glycemic variability and oxidative stress markers in Japanese patients with type 2 diabetes mellitus. Clin. Drug Investig. 2013, 33, 563-570. [CrossRef] [PubMed]

119. Sheard, N.F.; Clark, N.G.; Brand-Miller, J.C.; Franz, M.J.; Pi-Sunyer, F.X.; Mayer-Davis, E.; Kulkarni, K.; Geil, P. Dietary carbohydrate (amount and type) in the prevention and management of diabetes: A statement by the american diabetes association. Diabetes Care 2004, 27, 2266-2271. [CrossRef]

120. Lin, Y.-H.; Huang, Y.-Y.; Chen, H.-Y.; Hsieh, S.-H.; Sun, J.-H.; Chen, S.-T.; Lin, C.-H. Impact of Carbohydrate on Glucose Variability in Patients with Type 1 Diabetes Assessed Through Professional Continuous Glucose Monitoring: A Retrospective Study. Diabetes Ther. 2019, 10, 2289-2304. [CrossRef]

121. Frid, A.H.; Nilsson, M.; Holst, J.J.; Björck, I.M. Effect of whey on blood glucose and insulin responses to composite breakfast and lunch meals in type 2 diabetic subjects. Am. J. Clin. Nutr. 2005, 82, 69-75. [CrossRef]

122. Buscemi, S.; Cosentino, L.; Rosafio, G.; Morgana, M.; Mattina, A.; Sprini, D.; Verga, S.; Rini, G.B. Effects of hypocaloric diets with different glycemic indexes on endothelial function and glycemic variability in overweight and in obese adult patients at increased cardiovascular risk. Clin. Nutr. 2013, 32, 346-352. [CrossRef] 
123. Henry, C.J.; Kaur, B.; Quek, R.Y.C.; Camps, S.G. A Low Glycaemic Index Diet Incorporating Isomaltulose Is Associated with Lower Glycaemic Response and Variability, and Promotes Fat Oxidation in Asians. Nutrients 2017, 9, 473. [CrossRef]

124. Shukla, A.P.; Iliescu, R.G.; Thomas, C.E.; Aronne, L.J. Food Order Has a Significant Impact on Postprandial Glucose and Insulin Levels. Diabetes Care 2015, 38, e98-e99. [CrossRef] [PubMed]

125. Hashimoto, Y.; Kaji, A.; Sakai, R.; Osaka, T.; Ushigome, E.; Hamaguchi, M.; Yamazaki, M.; Fukui, M. Skipping breakfast is associated with glycemic variability in patients with type 2 diabetes. Nutrition 2020, 71, 110639. [CrossRef] [PubMed]

126. Rasmussen, L.; Christensen, M.L.; Poulsen, C.W.; Rud, C.; Christensen, A.S.; Andersen, J.R.; Kampmann, U.; Ovesen, P.G. Effect of High Versus Low Carbohydrate Intake in the Morning on Glycemic Variability and Glycemic Control Measured by Continuous Blood Glucose Monitoring in Women with Gestational Diabetes Mellitus-A Randomized Crossover Study. Nutrients 2020, 12, 475. [CrossRef] [PubMed]

Publisher's Note: MDPI stays neutral with regard to jurisdictional claims in published maps and institutional affiliations.

(C) 2020 by the authors. Licensee MDPI, Basel, Switzerland. This article is an open access article distributed under the terms and conditions of the Creative Commons Attribution (CC BY) license (http://creativecommons.org/licenses/by/4.0/). 